\title{
一家系に多発せる骨形成不全症
}

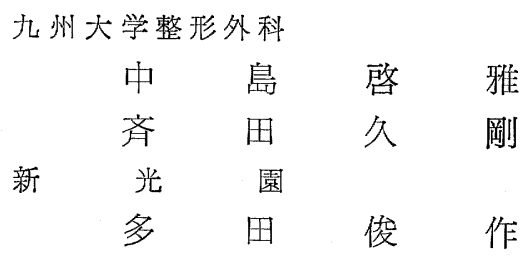

\section{Six Cases of Osteogenesis Imperfecta in One Family}

\author{
By \\ H. Nakashima \& H. Saita \\ Department of Orthopedic Surgery in Kyushu Univ. \\ S. Tada \\ Sinkoen Crippled Children Hospital
}

\begin{abstract}
Osteogenesis imperfecta has been reported more than 400 cases in Japan. But family cases are rare.

Osteogenesis imperfecta is characterized by fragility of bone, deafness, blue sclerotics and laxity of joints. We have experienced six cases in one family that consist of a mother, four sons and a granddaughter.

Our cases have suffered from fracture from several to about 16 times. Blue sclerotics was noticed in two cases of the family. Deafness was noticed in five cases except a granddaughter. Recurrent dislocation of shoulder was noticed in three cases of the family. Dwarfing was watched in all cases. Varus deformities of the femurs are dominant. Scoliosis of the vertebral bodies was in one case, hyperlordosis is in two cases, and kyphosis is in one case. But deformity and functional disturbances of upper extremity were within normal limits in all cases. Serum level of alkaline phosphatase was sightly elevated in one case.
\end{abstract}

\section{緒}

言

骨形成不全症は易骨折性, 難聴, 青色琗膜, 低身長, 関節弛緩, 歯牙形成不全などの 特異な 臨床症状をも ち，よく知られているが，幼児より病的骨折を起す例 として，1716 年 Chaussier の報告に初まり，1833年 Lobstein が Osteopsathyrosis idiopathica として はじめて独立疾患として記載した。我国では，明治 22 年三浦, 江波が「一畸形症」として報告して以来, 400 例をてえる.

遺伝性については，古くから言及されているが, 多 くは単発例であり, 兄弟例ましてや親子例は少ない。 我々は親子三代（母親, 子供 4 人, 孫娘 1 人) の稀な る骨形成不全症を有する 家系を 経験したので 報告す
る.

又, 症例 6 (9 歳) の右大腿骨折以外は医療を受け ていなかったのを附記する.

症例

症例 1 (72歳 女)

身長 $126 \mathrm{~cm}$, 現病歴: 30 歳頃より難聴となり現在 は全く槊であり，聴取が十分出来なかったが，早期よ り歯牙が悪かったといい，15年位前より，左大腿痛 があるという。

現症：青色㲧膜なし，白内障あり，胸廓は前方に突 出し, 円背をなしている. 左大腿は外方住突出してい るのが見える. 右肘は $175^{\circ}$ に内反し伸展 $160^{\circ}$ で伸展 障害がある。 
レントゲン所見は, 脊椎は透過性が増大し魚椎をな し, 大腿骨頭は中心性に移行し, 臼蓋も菲薄になって いる．大腿骨はなめらかな孤状をなしている．いずれ の症例についてもいえることだが，レントゲンの透過 性は增大し, 骨陰影は淡く, 骨梁は繊細で, 骨皮質は 薄い.

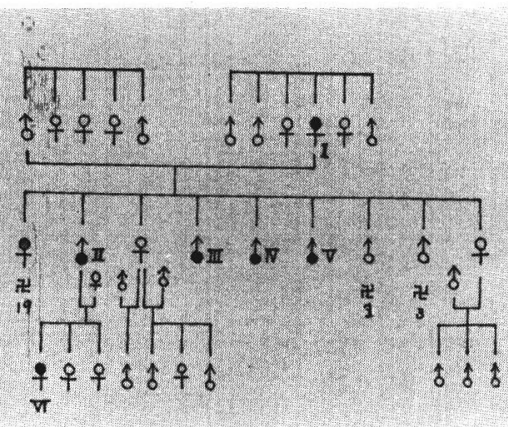

図1家系図

症例 2 (45 歳 男)

身長 $118 \mathrm{~cm}$, 体重 $32 \mathrm{~kg}$, 胸囲 $83 \mathrm{~cm}$.

現病歷：就学前に両大腿骨を数回骨折したことがあ る. 又11歳頃より両肩関節脱臼が 7 回位あるという. 45 歳になり, 左大腿骨骨折し, 整骨師にて 治療し 4 ケ月後に診察した時は骨癒合していた。歯牙は弱く 18 歳頃より入歯をしていた.

現症：顔貌は正常, 青色叕膜あり. 腰椎は後彎は強
いが，胸部には異常なかった，両大腿部にて前外方に 著しい突出がみえ， $145^{\circ}$ の外反膝があり．レントゲ ン所見として, 大腿上中 $1 / 3$ にて約 $45^{\circ}$ の鋭角にて変 形治癒骨折を来している. 聴力は Audiogram にて 高度の伝音系難聴であった。

症例 3(40歳 男)

身長 $118 \mathrm{~cm}$, 体重 $31 \mathrm{~kg}$, 胸囲 $77 \mathrm{~cm}$.

現病歴：4歳頃より, 1 年に $2 \sim 3$ 度, 12 歳頃まで よく両大腿骨を骨折したという. 又左習慣性肩関節脱 臼があったという。

現症：青色琗膜なし, 難聴あり,下顎の発達は悪い. 胸椎に右凸の Primory courve をむつ側彎あり, 腰 椎は左凸の側後彎を呈している，両大腿部に外側の突 出がみえる. 右滕は $150^{\circ}$ の外反滕がありかつ, $30^{\circ}$ の 反張がある，左滕は $130^{\circ}$ の屈曲位にて起立してい る.

レントゲン所見として，両大腿骨は転子下部に頂点 をむつ内反変形をなしているが骨頭の内反が強く, そ のためか，大転子が異常に大きくなり，これに対応 し，新しい曰蓋を形成している.

症例 4 (38歳男)

身長 $135 \mathrm{~cm}$, 体重 $38 \mathrm{~kg}$, 胸囲 $80 \mathrm{~cm}$.

現病歴：20歳頃より 両大腿部が 3 度 骨折したとい う.

現症：青色䐙膜なし, 難聴あり. 両大腿部の内反変 形があるが, 脊椎に著変なし.

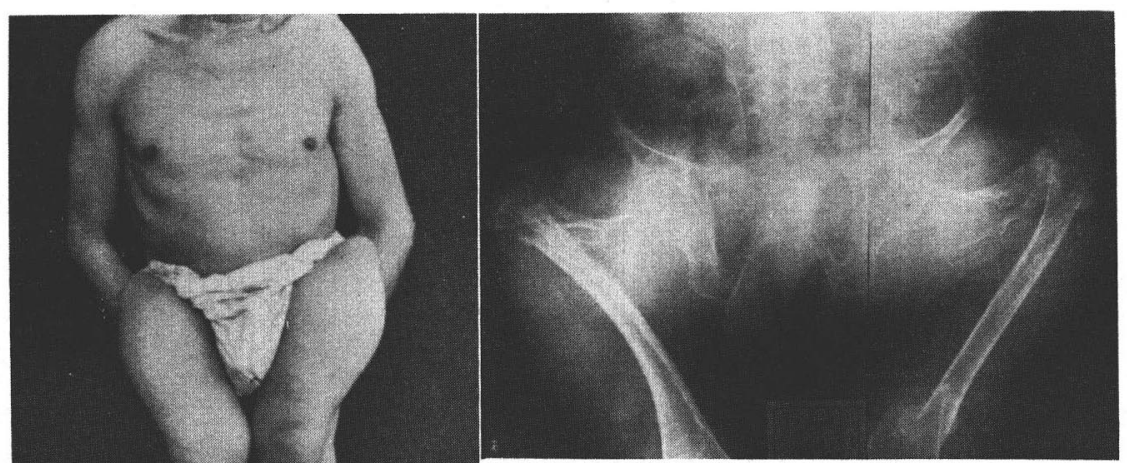

図 2 症 例 II 


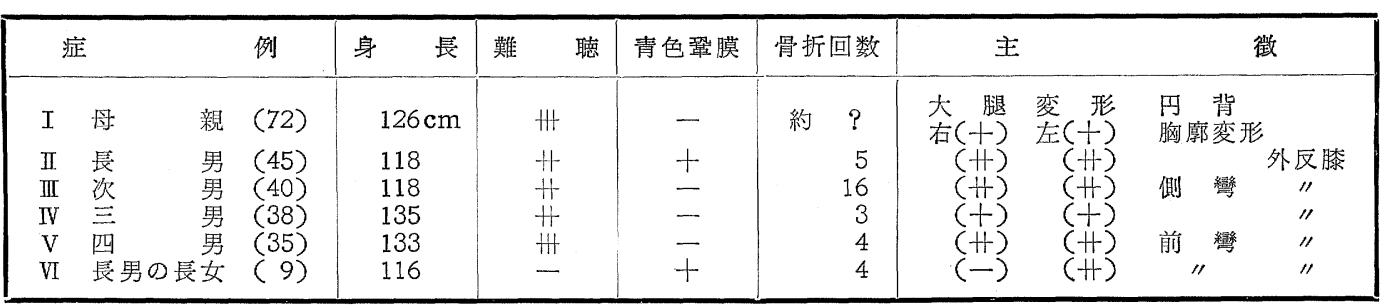

\section{症例 5 (35 歳 男)}

身長 $133 \mathrm{~cm}$, 体重 $30 \mathrm{~kg}$, 胸国 $76 \mathrm{~cm}$.

現病歴: 両大腿部が 9 歳頃より $3 \sim 4$ 回骨折したよ いう. 又左肩 2 回, 右肩 1 回の脱臼がある.

現症：青色腪膜なし，難聴あり，両下肢共，大腿よ り $90^{\circ}$ 外捻し, その為, 滕は前後屈が出来ず, 内側に 屈曲しか出来ない. $160^{\circ}$ の両外反膝がある. 又腰椎 の前彎が強いレントゲン所見として，右転子部にて約 $40^{\circ}$ 左転子部にて約 $70^{\circ}$ の鋭角で変形治癒骨折を 来 し，そのため大転子が骨盤に接している。

\section{症例 6 ( 9 歳 女)}

身長 $116 \mathrm{~cm}$, 体重 $15 \mathrm{~kg}$, 胸囲 $56 \mathrm{~cm}$.

現病歴: 生後 14 日目に右大腿骨骨折に気付き, ス ポンジ率引を受けたととがある５歳の時積みかさね たフトンの上より飛びおり，左大腿骨骨折を来したの をはじめ計 4 回位の骨折歴がある.

現症 : 青色琗膜あり, 難聴なし, 左大腿部にて前外 方凸の著明な変形がみえ，脚長差が $7 \mathrm{~cm}$ あり, 左膝 は $20^{\circ}$ の反張があり尖足にて歩行していた。レントゲ ン所見として，左大腿上中 $1 / 3$ にて，70 の鋭角にて 変形治癒骨折をおこしていたので，変形矯正の目的で 手術を行なった。はじめふとい髄内鎬による強固な固 定を行なう予定であったが，骨皮質はうすく，脆いた め, 太めのキルシュナーによる固定と外固定を行なっ
た.

以上の 6 例の他に長女は 19 歳で死亡したが 身長は 低かったという。

血清電解質しして Ca，P，Al-Phos を検査し，症 例 1 の A1-Phos が $16.2 \mathrm{~K}-\mathrm{A}$ 単位とやや高值を示す 以外は正常であった.

\section{ま と め}

以上，一家系飞母親，兄弟 4 人，孫娘 1 人と親子 3 代にわたる骨形成不全症の家系を経験したので，報告 した。

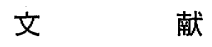

1) 竹林：日整会誌. 17:975, 1942 .

2）丸毛：日整会誌。24:116, 1949.

3) 浦山: 整形外科. 1:99, 1950.

4) 遺伝医学. 417 .

5）花北：整形外科. 14:1101, 1963.

6) 後藤：整形外科. $19: 836,1968$.

7）加倉井：整形外科. $21: 167,1970$.

8）加倉井：整形外科. $21: 355 ， 1970$.

9）天児・活加：骨関節 X線診断図譜 II. 59.

10) Ferguson : Orth. Surg. in infancy and childhood sec. edition. 517.

11) Turek: Orthopedics. 171.

12) Nelson: Text book of Pediatrics 8ed. 1342. 